\title{
The littoral benthon community of Lake Orta after liming: a comparison between summer 1993 and summer 1998
}

\author{
Ettore BIELLI* and Marina TESAURO \\ Agenzia Regionale per la Protezione Ambientale - Dipartimento di Novara, Viale Roma 7e, 28100 Novara, Italy \\ *e-mail corresponding author: e.bielli@arpa.piemonte.it
}

\begin{abstract}
At different times in recent years (before, during and after liming) we have studied the littoral macrobenthonic community in Lake Orta, and, for comparison, in Lake Mergozzo (an unpolluted lake). In this paper we compare the situations after liming in summer 1993 and in summer 1998. We found no clear difference between the summer samples in 1993 and 1998 for each site; only seasonal fluctuations were in evidence, in particular in the sites of Gozzano and Pella and in Lake Mergozzo. The two lakes, however, still present marked differences in the composition of their macrobentonic communities.
\end{abstract}

Key words: Lake Orta, littoral benthos, liming

\section{INTRODUCTION}

This research was conducted on Lake Orta, a subalpine lake in north-western Italy, which began to be affected by industrial pollution at the end of the twenties. Phytoplankton, zooplankton, benthos and necton suffered severe consequences from the impact of high copper concentrations and low $\mathrm{pH}$ (Monti 1930; Baldi 1949; Vollenweider 1963). A restoration project to bring $\mathrm{pH}$ and alkalinity back to their natural values (Bonacina et al. 1987) was implemented from 1989 to 1990 with the massive introduction of about $10,900 \mathrm{t}$ of $\mathrm{CaCO}_{3}$ (liming).

The aim of the study was to analyse the post-liming composition of the littoral macrobenthonic community of Lake Orta in the summers of 1993 and 1998. At the same time a comparison was made between the macrobenthonic community of Lake Orta and that of Lake Mergozzo, a nearby unpolluted lake with similar lithologic characteristics and a similar trophic level, as calculated on the basis of the volume/inhabitants ratio.

Other information about the presence - absence of taxa in Lake Orta before (1987 and 1988) during (1990) and after the liming (1992 and 1993) can be found in Tesauro et al. (1995).

\section{MATERIAL AND METHODS}

We studied five stations in Lake Orta and one in Lake Mergozzo (Fig. 1 and Tab. 1). All of them were characterized by the presence of clumps of Phragmites communis. The samples were collected in June and in August 1993 and in July and September 1998. Bottom samples were taken using a square hand net $(25 \mathrm{~cm}$ wide), for $30 \mathrm{~min}$. over an area of about $1 \mathrm{~m}^{2}$. The animals were first isolated and then classified in the laboratory.
For the purposes of this study we calculated the two Shannon diversity indexes in each sampling site.

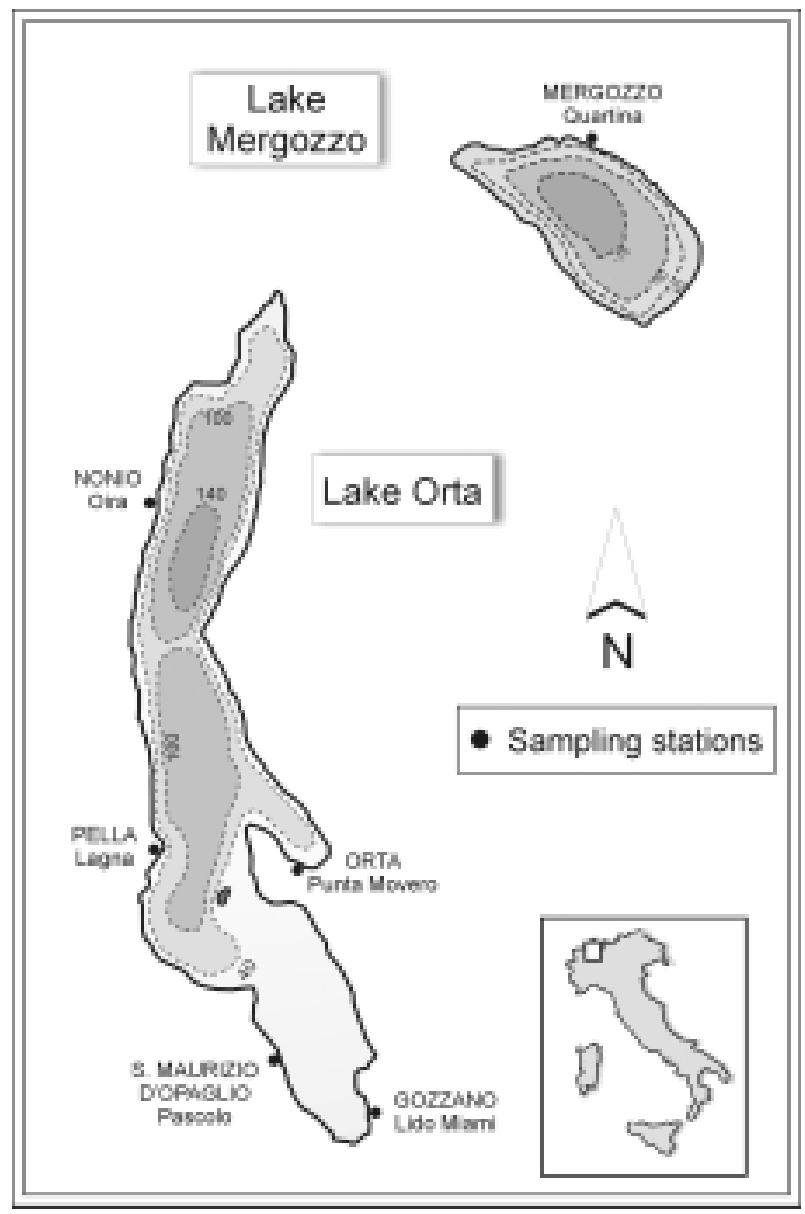

Fig. 1. Lake Orta and Lake Mergozzo stations. 
Tab. 1. List of the sampling sites.

\begin{tabular}{lll}
\hline Town & Locality & Tipology \\
\hline Nonio & (1) Oira & Partially urbanised area, very steep slope \\
Pella & (2) Lagna & Mixed forest, from mild to steep slope \\
San Maurizio d'Opaglio & (3) Pascolo & Meadows, forest, mild slope \\
Gozzano & (4) Lido Miami & Scrub with shrub, locusts, alders, mild slope, then steep \\
Orta & (5) Punta Movero & Artificial bank, mild slope, then steep \\
Mergozzo & (6) Quartina & Meadows and scrubs, mild slope, then steep \\
\hline
\end{tabular}

Tab. 2. List of the taxa collected in every site in summer 1998. For comparison we reported taxa collected in summer 1993 and in winter 1987-88 (before liming). Presence $=+$.

\begin{tabular}{|c|c|c|c|c|c|c|c|c|c|c|c|c|c|c|c|c|c|c|c|c|c|c|c|c|c|c|}
\hline & & & & Pas & colo & & & $\mathrm{Pe}$ & ella & & & & ira & & & Goz & zzano & & & & Orta & & & Mer & gozz & \\
\hline & & & $\overline{\mathrm{XII}}$ & VI & VIII & $\overline{\mathrm{VII}}$ & $\bar{X}$ & VI & VIII & $\overline{\mathrm{VII}}$ & $\overline{\mathrm{XII}}$ & VI & VIII & $\overline{\mathrm{VII}}$ & $\overline{\text { XII }}$ & I VI & VIII & IX & $\overline{\mathrm{XII}}$ & VI & VIII & $\bar{I}$ IX & $\mathrm{I}$ & & VIII & I IX \\
\hline & & & 87 & 93 & 93 & 98 & 87 & 93 & 93 & 98 & 87 & 93 & 93 & 98 & 87 & 93 & 93 & 98 & 87 & 93 & 93 & 98 & 88 & 93 & 93 & 98 \\
\hline Ephemeroptera & Fam. Caenidae & Caenis horaria & & & & & & & & & & & & & & & & & & & & & + & & + & + \\
\hline & Fam. Baetidae & $\begin{array}{l}\text { Centroptilum luteolum } \\
\text { Cloeon } \mathrm{sp} .\end{array}$ & & & & & & & & & & & & & & & & & & & & & & & + & + \\
\hline Tricoptera & Fam. Leptoceridae & $\begin{array}{l}\text { Mystacides azurea } \\
\text { Oecetis } \mathrm{sp} .\end{array}$ & + & + & + & $\begin{array}{l}+ \\
+\end{array}$ & + & + & $\begin{array}{l}+ \\
+\end{array}$ & $\begin{array}{l}+ \\
+\end{array}$ & + & + & + & + & & + & $\begin{array}{l}+ \\
+\end{array}$ & $\begin{array}{l}+ \\
+\end{array}$ & + & + & + & $\begin{array}{l}+ \\
+\end{array}$ & + & + & + & $\begin{array}{l}+ \\
+\end{array}$ \\
\hline & Fam. Psycomidae & Lype sp. & & & & & & & & & & & & & & & & & & & & & & + & + & \\
\hline & Fam. Limnephilidae & Limnephilus rhombicus & & & & & & & & & & & & & & & & & & & & & & + & & \\
\hline & & Limnephilus sp. & & & & & & & & & & & & & & & & & & & & & + & & & + \\
\hline & Fam. Ecnomidae & Ecnomus tenellus & + & + & + & + & & + & + & + & + & + & + & + & + & + & + & + & + & + & + & + & + & & + & + \\
\hline & Fam.Phryganeidae & Agrypnia varia & & & & & & & & & + & & & & + & & & & + & & & & & & & \\
\hline Odonata & Fam. Libellulidae & Pyrrosoma nimphula & + & & & & & & & & & & & & & & & & & & & & & & & \\
\hline & & Libellula depressa & & & & & & & & & & & & & + & + & + & + & + & & & & & & + & + \\
\hline & Fam. Coenagrionidae & Ischnura elegans & & + & + & & & + & + & & + & + & + & & & & & & & + & + & + & & + & + & + \\
\hline & Fam. Cordulidae & Somatochlora metallica & & & + & + & & & & & + & & + & + & & + & + & + & & + & + & + & & & & \\
\hline & Fam.Lestidae & Erythroma viridulum & & & & & & & & & & & & & & & & & & & & & + & & & \\
\hline Megaloptera & Fam. Sialidae & Sialis sp. & & & & & & & & & + & & & & + & & & + & & & & & + & + & + & + \\
\hline Diptera & Fam.Chironomidae & & + & + & + & + & + & + & + & + & + & + & + & + & + & + & + & + & + & + & + & + & + & + & + & + \\
\hline & Fam. Ceratopogonidae & & & + & + & + & & & & + & & & & + & + & & + & + & & & + & + & + & + & & + \\
\hline & Fam.Psycodidae & & & & & & & & & & & & & + & & & & & & & & & & & & \\
\hline Eteroptera & Fam.Corixidae & Micronecta meridionalis & & + & & & & & & & & & & + & & + & + & & & & & & + & & & \\
\hline Coleoptera & Fam. Elminthidae & Esolus angustatus & & & & & & & & & & & & & & & & & & & & & & + & & \\
\hline & Fam. Dytiscidae & & & & & & & & & & & & & & & + & & & & & & & & & & \\
\hline Oligochaeta & Fam.Tubificidae & & + & + & + & + & + & & + & & + & + & & + & + & + & + & + & + & + & + & + & & + & + & + \\
\hline & Fam. Naididae & & & & & & & & & & & & & & & + & & & & & + & & + & & & + \\
\hline & Fam.Lumbricidae & & & & & & + & & & + & & & & + & & & & + & & & & + & + & & & + \\
\hline & Fam.Lumbriculidae & & & & + & + & & & & & & & + & + & & & & & & & + & & + & & + & \\
\hline Nematoda & Fam. Mermithidae & & & & & & & & + & & & & & & & & & & & & + & & & + & + & \\
\hline Hyrudinea & Fam. Glossiphonidae & Helobdella stagnalis & & & & & & & & & & & & & & + & & & & & & & & & & + \\
\hline & & Glossiphonia complanata & & & & & & & & & & & & & & & & & & & & & + & & & \\
\hline & Fam.Erpobdellidae & Erpobdella sp. & & + & + & & & & + & & & + & + & & & & + & & + & + & + & + & & & + & \\
\hline & & $\begin{array}{l}\text { Erpobdella testacea } \\
\text { Erpobdella octoculata }\end{array}$ & + & + & & + & + & + & & & + & + & & & + & $\begin{array}{l}+ \\
+\end{array}$ & & + & & & & & + & $\begin{array}{l}+ \\
+\end{array}$ & & \\
\hline Tricladida & Fam. Dugesiidae & Dugesia tigrina & & & & & & & & & & & & & & & & + & & & & & + & + & & \\
\hline & & Dugesia gonocephala & & & & & & & & & & & & & & + & & & & & & & & & & \\
\hline & & Dendrocoelum lacteum & & & & & & & & & & & & & & & & & & & & & + & + & & + \\
\hline & Fam. Planaridae & Polycelis sp. & & + & & & & & & & & & & & & & & & & & & & & & & \\
\hline Gasteropoda & Fam.Lymneadae & Limnaea auricularia & & & & & & & & & & & & & & & & & & & & & + & + & & + \\
\hline & Fam. Physidae & Physa fontinalis & & & & & & & & & & & & & & & & & & & & & & & & + \\
\hline & & Physa acuta & & & & & & & & & & & & & & & & & & & & & + & & & \\
\hline & Fam.Valvatidae & Valvata piscinalis & & & & & & & & & & & & & & & & & & & & & + & & + & \\
\hline & & Valvata cristata & & & & & & & & & & & & & & & & & & & & & + & & & \\
\hline Crustacea & Fam. Asellidae & Asellus aquaticus & & & & & & & & & & & & & & & & & & & & + & + & + & & + \\
\hline
\end{tabular}

\section{RESULTS}

Table 2 indicates the presence or absence of taxa among those collected after the liming in summer 1993 and summer 1998. For comparison, data are also provided on taxa collected in winter 1987-1988; these are the only data available for the same stations which refer to the period before the liming.

The littoral macrobenthonic biocoenosis of Lake Orta is characterised by the continuous presence of
Trichoptera (Mystacides azurea, Ecnomus tenellus), Odonata (Ischnura elegans), Diptera (Fam. Chironomidae), Hirudinea (Erpobdella sp.), and Oligochaeta (Fam. Tubificidae) in every site.

Other taxa belonging to Trichoptera (Oecetis sp.), Odonata (Somatochlora metallica), Diptera (Fam. Ceratopogonidae) and Oligochaeta (families Lumbricidae and Lumbriculidae) appear to be present discontinuously. There was also a variable distribution of Eteroptera (sites 3 and 4), Coleoptera and Megaloptera (site 4), and Crustacea (site 5). 
On a single occasion we collected organisms belonging to the Fam. Psycodidae (Diptera) at station 1, and to the families Dugesiidae and Planaridae (Tricladida) at stations 3 and 4 respectively. Moreover, in 1998 we noticed the disappearance of Agrypnia varia (Trichoptera, Phryganeidae), a species adapted to acid aquatic environments.

In Lake Mergozzo, the above listed taxa are present, as well as Ephemeroptera (Caenis horaria, Centroptilum luteolum, Cloeon sp.) and Gasteropoda (Limnaea auricularia, Physa fontinalis, Valvata piscinalis). Oligochaeta and Trichoptera are always present with a varying number of species.

Table 3 reports and compares the number of organisms $\mathrm{m}^{-2}$ in each site for every period of observation. The difference between the two lakes is evident: a greater number of benthonic organisms is present in Lake Mergozzo. In Lake Orta during 1998, the lowest number of organisms $\mathrm{m}^{-2}$ (only 32) was found in station 1 , the highest (53) in station 4.

Tab. 3. Total number of organisms $\mathrm{m}^{-2}$.

\begin{tabular}{lccc}
\hline & June '93 & August '93 & July-September '98 \\
\hline S.MAURIZIO & 83 & 96 & 44 \\
PELLA & 28 & 82 & 52 \\
NONIO & 37 & 31 & 32 \\
GOZZANO & 102 & 54 & 53 \\
ORTA & 47 & 41 & 50 \\
MERGOZZO & 158 & 96 & 141 \\
\hline
\end{tabular}

Table 4 shows the comparison between the total number of taxa collected in each sample.

Tab. 4. Total number of taxa collected in each sample.

\begin{tabular}{lccc}
\hline & June '93 & August '93 & July-September '98 \\
\hline S.MAURIZIO & 10 & 9 & 9 \\
PELLA & 5 & 8 & 6 \\
NONIO & 7 & 7 & 9 \\
GOZZANO & 14 & 9 & 12 \\
ORTA & 7 & 11 & 11 \\
MERGOZZO & 15 & 14 & 21 \\
\hline
\end{tabular}

In both periods Lake Mergozzo is characterised by a greater number of taxa than Lake Orta.

Sites 4 and 5 (both on the eastern shore of Lake Orta) present a greater number of taxa than the sites located on the opposite shore. In particular, the lowest number of taxa was observed at site 2 . This was possibly because of its proximity to the River Lagna and the River S. Filiberto outlets, which collect industrial treatment plant discharges (often loaded with heavy metals for the presence of galvanic industries) coming from San Maurizio d'Opaglio and from Pella.

Table 5 reports the Shannon indexes referring to June-August 1993 and July-September 1998. Shannon index values present a similar trend to that indicated for the taxa, confirming previous observations. Once again station 2 is the site with the lowest Shannon index value, while station 4 has the highest.

Tab. 5. Shannon index values for each site and sample.

\begin{tabular}{lccc}
\hline & June '93 & August '93 & July-September '98 \\
\hline S.MAURIZIO & 1.3 & 1.3 & 1.5 \\
PELLA & 1.4 & 1.5 & 1.0 \\
NONIO & 1.4 & 1.8 & 1.7 \\
GOZZANO & 2.2 & 2.1 & 2.0 \\
ORTA & 1.5 & 2.1 & 1.6 \\
MERGOZZO & 1.8 & 1.9 & 2.4 \\
\hline
\end{tabular}

\section{CONCLUSIONS}

In Summer 1998 research was continued on the littoral macrobenthonic community in lakes Orta and Mergozzo. We believe that the situation is stable, with no visible changes being recorded, except for the already cited disappearance of Agrypnia varia. No new taxa were found and no particular difference in abundance is evident, although there is definitely a seasonal variation in the littoral macrobenthonic community. A decrease in the number of taxa from August 1993 to July 1998 was noticed only in site 4 . There are still differences in the composition of the macrobenthonic community of each lake.

Gasteropoda and Crustacea, some genera or species belonging to Ephemeroptera (Caenis horaria, Cloeon sp., Centroptilum luteolum), Coleoptera (Esolus angustatus), Hirudinea (Helobdella stagnalis) and Tricladida (Dendrocoelum lacteum) are present only in Lake Mergozzo. The possible causes of such differences may lie in the difficulty of recolonization, or the presence of heavy metals in the sediments in Lake Orta.

We found on only one occasion an Asellus aquaticus (Asellidae, Crustacea) in Lake Orta; whether this is an occasional presence, or an organism belonging to a stable population, will be verified in our next studies. In both lakes the study of these communities will be aimed especially at verifying the spatial-temporal evolution of macrobenthonic populations.

\section{REFERENCES}

Baldi, E. 1949. Il Lago d'Orta, suo declino e condizioni attuali. Mem. Ist. ital. Idrobiol., 5: 145-188.

Bonacina, C., G. Bonomi, A. Calderoni \& R. Mosello. 1987. Evoluzione recente dell'inquinamento del Lago d'Orta e proposta di un intervento per il suo recupero. Documenta Ist. ital. Idrobiol., 14:197-213.

Monti, R. 1930. La graduale estinzione della vita nel lago d'Orta. Rend. Ist. Lombardo. Sc. Lett., 63: 3-22.

Tesauro, M., E. Bielli, M. Cotta Ramusino \& B. Rossaro. 1995. The littoral benthon of Lake Orta after liming. Mem. Ist. ital. Idrobiol., 53: 213-230.

Vollenweider, R.A. 1963. Studi sulla situazione attuale del regime chimico e biologico del Lago d'Orta. Mem. Ist. ital. Idrobiol., 16: 21-125. 